\title{
Child Separation
}

\section{(Post)Colonial Policies and Practices in the Netherlands}

\author{
and Belgium
}

\author{
GEERTJE MAK, MARIT MONTEIRO AND ELISABETH \\ WESSELING
}

Children were central to Dutch and Belgian colonial projects. Children and youth were the objects of colonial interventions issued by missionaries and officials. However, children could also become actors who produced change in a colonial context. Crucial in colonial policies towards children was the separation of children from their parents, communities and/or culture ('child separation') in all kinds of forms - temporary or permanent, far from home or close by, in contact with their own community or cut off from it - and to various degrees of coercion (voluntary, from a situation of dependence, enforced with punishment or violence). Child separation projects could involve adoption, foster parenting, 'apprenticeships' serving a household, boarding schools or day schools. It could concern children from the local elite, but also children who ended up on the margins of their own communities or were even bought out of slavery. Child separation was never about education only, but always imposed specific morals and life styles on its subjects as well. It caused profound fault lines in colonised families and communities. For colonial politics, it was key to controlling, influencing and disciplining the colonised population ('governmentality'). In the case of children of ethnically mixed descent, child separation often involved policing hierarchical racialised boundaries in the colony; in the case of indigenous children, it aimed at transforming the colonised population. Christian missions were pivotal in child separation projects. This special issue, therefore, pleads for a more central place of Catholic and Protestant missions in the analysis of Dutch colonial history, comparable to Belgian historiography. Finally, it is precisely these (missionary) 
colonial projects, often labeled as 'soft' or 'civilising', that have passed unnoticed into post-colonial discourses, organisations and practices, such as transnational adoption or surrogacy, and countless development projects in which children, detached from their own family and context, must be 'saved'. Without proper scholarly attention for Christian missions in colonial history, these traces of the colonial past in the postcolonial present will not be recognised as such.

Kinderen stonden centraal in Nederlandse en Belgische koloniale projecten. Kinderen en jongeren waren daarbij het object van koloniaal handelen van missionarissen, zendelingen en ambtenaren, maar zij konden ook zelf actoren worden die in een koloniale context veranderingen veroorzaakten. Cruciaal in deze koloniale projecten was het scheiden van kinderen van hun ouders, van hun gemeenschappen en van hun cultuur (child separation) in allerlei vormen - tijdelijk of voorgoed, ver van huis of dichtbij, in contact met de eigen gemeenschap of volledig daarvan afgesneden - en in diverse gradaties van dwang (vrijwillig, vanuit een situatie van afhankelijkheid, afgedwongen met straffen of geweld). Concreet kon het gaan om adoptie, pleegouderschap, het in huis nemen van werkende 'leerjongens en -meisjes', kostscholen of dagscholen. De kinderen zelf waren afkomstig uit de lokale elite, of het waren juist kinderen die in de marge van hun eigen gemeenschappen terecht waren gekomen, of zelfs door missionarissen uit slavernij werden gekocht. De doelstellingen van deze praktijken betroffen nooit alleen onderricht, maar altijd ook het aanleren van een bepaalde levenswijze en moraal. Niet alleen veroorzaakten de scheiding en heropvoeding ingrijpende breuklijnen in gekoloniseerde families en gemeenschappen; voor de koloniale politiek waren deze kinderen de sleutel tot het controleren, beïnvloeden en disciplineren van de gekoloniseerde bevolking (governmentality). In het geval van kinderen van etnisch gemengde komaf ging het vaak om het bewaken van de hiërarchische geracialiseerde grenzen in de kolonie; in het geval van lokale kinderen meer om het transformeren van de gekoloniseerde bevolking. Van veel instellingen voor opvoeding en onderwijs van deze kinderen vormden christelijke missie- en zendingsorganisaties de spil. In en met dit themanummer wordt daarom ook een lans gebroken voor de integratie van missie en zending in het analyseren van de Nederlandse koloniale geschiedenis, in navolging van de Belgische historiografie. Tot slot zijn het juist deze vaak als 'zacht' of 'civiliserend' aangemerkte koloniale projecten die ongemerkt zijn overgegaan in postkoloniale discoursen, organisaties en praktijken, zoals transnationale adoptie of draagmoederschap, en talloze ontwikkelingsprojecten waarin kinderen, losgezongen van hun eigen familie en context, 'gered' moeten worden. Zonder gedegen wetenschappelijke aandacht voor de rol van christelijke missie- en zendingsorganisaties in de koloniale geschiedenis zullen deze sporen van het koloniale verleden in het postkoloniale heden niet als dusdanig worden herkend. 


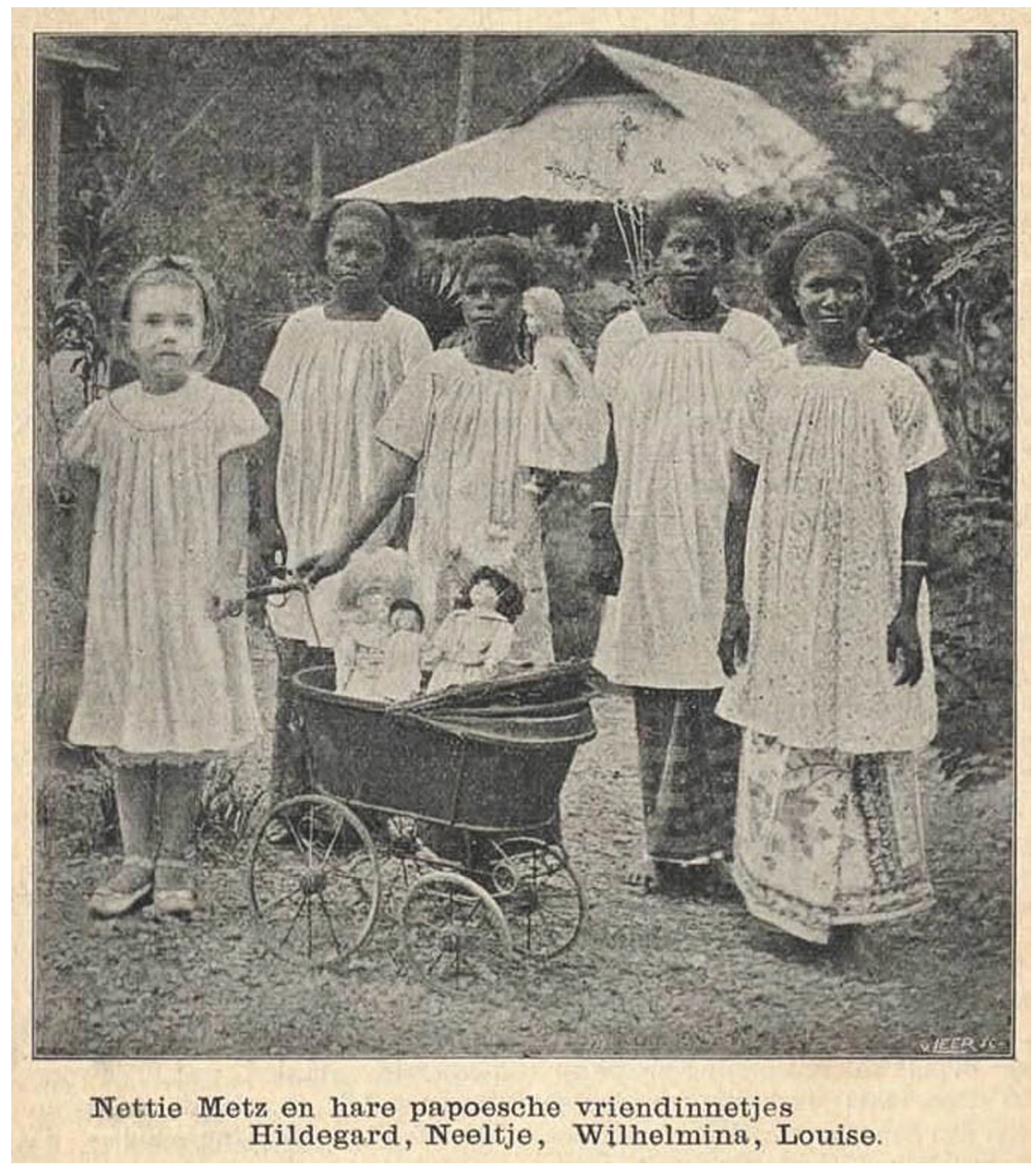

$\Delta$

A photo of the missionaries' daughter 'Nettie Metz with her Papuan friends Hildegard, Neeltje, Wilhelmina and Louise' at Doreh (Dutch New Guinea). Their Dutch names indicate that these Papuan girls were either part of the missionaries households, or of one of the Papuan Christian families at Doreh. One of the strategies of Dutch missionaries in Dutch New Guinea was to teach girls and young women how to raise and educate their children. This photo symbolically points to the future of Papuan women raising children in Dutch ways. However, the framing of the photo with Nettie Metz as the central subject contrasts her to the others (labelled both as 'Papuan' and, in the accompanying text as 'black'). Moreover, subtle but clear differences in clothing (Dutch fashion versus sarong and kabaja, shoes versus bare feet) betray colonial mimicry - Homi K. Bhabha's famous 'almost the same, but not quite'. The photo was published in Het Penningske in 1906, a journal directed at Dutch youth. ${ }^{1}$

1 Het Penningske 6:12 (1906) 1. https://resolver.kb.nl/

resolve?urn=MMZEND01:002721012:00001 


\section{Child separation: introduction ${ }^{2}$}

According to Karen Vallgårda, the involvement of the Danish Christian mission with children in India during the late nineteenth and early twentieth century, 'underwrote a construal of imperialism within Europe and North America as a project of white adults saving brown children from brown adults, an image that persists in present-day humanitarian discourses about children in the Global South'. ${ }^{3}$ This special issue is a first step in questioning this very construal for the (post)colonial histories of the Low Countries. We will do so, in the first place, by persistently asking whether and how European missionaries or aid workers could separate colonised children or children from the South from their parents, kin, community and culture to be adopted, boarded, raised or educated according to Western values, attitudes and lifestyles. How could this be 'sold' to Western audiences as benign, helpful and humanitarian? What kinds of practices were involved, and under which concrete circumstances could this take place? We thus hope to undo its seeming self-evidence and inquire into one of the mainstays of colonial power.

Internationally, the Australian 'Stolen Generations' constitute the bestknown example of an exceptionally violent form of colonial child removal. Studies into this colonial strategy have inspired a lot of further research into a larger variety of 'child separation' practices under both settler and extraction colonial regimes. Besides forcible and permanent removal and appropriation, child separation may involve manumission from enslavement and subsequent fostering; discursive, legal and actual 'orphaning' or 'dekinning'; forced or consensual stay at orphanages and boarding schools; consented or coerced fostering or adoption; or civilising and disciplining programmes at day schools. They all implied both the physical separation and discursive distancing of children from their parents' community and culture, but differed widely in form, degree of violence and coercion, permanency and degree of institutionalised, legal grounding. Moreover, multiple actors may have been involved, such as colonial officials, missionaries, European and indigenous teachers, European and local adoption agencies as well as the child's community, kin, parents of children or youth themselves. To cover these varieties in one term, we will label them as policies and practices of 'child separation'. This special issue will present a variety of microhistorical

This special issue is the first outcome of an initiative of the guest editors to organise an international collaborative project that zooms in on local or 'indigenous' children as objects and agents of (post)colonial change (COACC).

For more information, see https://ash.uva.nl/ content/projects/coac/coac.html.
The international cooperation is financed by the Dutch Organisation for Scientific Research (NWO).

3 Karen Vallgårda, Imperial Childhoods and Christian Mission: Education and Emotions in South India and Denmark (Basingstoke 2015) 3. DOI: https://doi. org/10.1057/9781137432995. 
case studies to demonstrate the many shapes such discourses and practices of separating children adopted, as well as the variety of agents involved.

In this introduction, we will first outline a triple conceptual framework grounded in 'new imperial history' - a socio-cultural approach of imperialism focusing on the complex constructions of colonial categories as well as the entanglements of metropole and colony. ${ }^{4}$ From this perspective, we approach the issue of child separation. It consists of: (a) awareness of the mutual influences between colony and metropole, particularly through civilising projects; (b) an understanding of colonial power on the basis of governmentality, enriched with insights from gender historians; and (c) a focus on religion within colonial policies and 'grammars of difference'. We will describe the international literature on child separation from these angles, and discuss the scarce and isolated studies on this topic within Low Countries historiography.

Subsequently, we will explain our approach of persistently questioning the how of child separation. What kinds of missionary and (post)colonial narratives, frames and labels created the discursive space legitimating interventions? How did missionaries, colonial administrators, European and indigenous teachers or adoption agencies realise 'child separation' in practice, and how had children become 'available' to such interventions to begin with? Which responses did these evoke among the communities, parents and children or youth involved? Asking such questions has led us to archives relatively absent from Dutch colonial historiography. As Protestant and Catholic missions were key actors in child separation, many of the authors of this issue started to explore missionary archives from a perspective distinctly different from classical missionary histories, as we will explain. This opened up a range of rich, as yet unexplored source material on embodied colonial encounters. It also added 'religion' as a crucial dimension of colonial hierarchies, a dimension often overseen in Dutch historiography, contrary to Belgian historiography. Finally, we will touch on the postcolonial continuities of colonial child separation practices, pointing to what James Heartfield and later Amalia Ribi Forclaz have called 'humanitarian imperialism'. ${ }^{5}$ By puncturing cultural amnesia concerning colonial child separation projects, this special issue hopes to contribute to better historical perspectives on contemporary child reallocation across national borders,

Foundational to this approach was Frederick

Cooper and Ann Laura Stoler, Tensions of Empire:

Colonial Cultures in a Bourgeois World (Berkeley

1997); see for the Dutch context: Remco Raben,

'A New Dutch Imperial History? Perambulations

in a Prospective Field', BMGN - Low Countries

Historical Review 128:1 (2013) 25-27. DOI: https://doi.

org/10.18352/bmgn-Ichr.8353.
5 James Heartfield, The Aborigines' Protection

Society: Humanitarian Imperialism in Australia,

New Zealand, Fiji, Canada, South Africa, and

the Congo, 1836-1909 (New York 2011); Amalia

Ribi Forclaz, Humanitarian Imperialism: The

Politics of Anti-Slavery Activism, 1880-1940

(Oxford 2015). DOI: https://doi.org/10.1093/

acprof:oso/9780198733034.001.0001. 
but also to stimulate further research into the continuities between colonial (missionary) humanitarianism and the current global 'charity industry'.

\section{New Imperial History \\ Civilising subjects}

There is an extensive international historiography on (late) colonial discourse presenting itself as helping, civilising, educating, uplifting, saving or developing colonised peoples. In the Netherlands, in particular the work of Elsbeth Locher-Scholten, Frances Gouda, Marieke Bloembergen and Remco Raben has pointed to this aspect of colonialism. ${ }^{6}$ Feminist analyses of colonialism such as the by now classical studies of Antoinette Burton and Catherine Hall, or the Dutch work done by Berteke Waaldijk, Maria Grever and Mineke Bosch, have uncovered the intricate relation between such colonial discourses and the emancipatory opportunities for European women to become accepted as national citizens by taking up colonial 'maternal' responsibilities. ${ }^{7}$ In Belgian historiography, this 'soft' counterpart of colonial exploitation and violence in Congo is primarily addressed in studies on the role of missionaries in education and medicine. ${ }^{8}$ However, while children and the metaphorical 'childishness' of colonised people were part of such civilising discourses, the actual practices of child separation were not addressed in these studies. Over the past ten years historians of European colonialism have started to realise that this colonial discourse not only metaphorically represented colonised people as children who had to be 'raised', but that in actual practice, colonial projects of 'civilisation' often literally targeted children and youth.

In 2005, Margaret Jacobs was one of the first to point out how settler colonial policies with regard to First Nation children in North America, in particular their temporary or permanent removal from their own families, was Colonial State: Essays on Gender and Modernity in the Netherlands Indies 1900-1942 (Amsterdam 2000); Julia Clancy-Smith and Frances Gouda, Domesticating the Empire: Race, Gender, and Family Life in French and Dutch Colonialism (Charlottesville 1998); Marieke Bloembergen and Remco Raben (eds.), Het koloniale beschavingsoffensief: Wegen naar het nieuwe Indië, 1890-1950 (Leiden 2009).

7 Antoinette M. Burton, Burdens of History: British Feminists, Indian Women, and Imperial Culture, 1865-1915 (Chapel Hill 1994); Maria Grever and Berteke Waaldijk, Transforming the Public Sphere: 
related to white women trying to obtain public rights of speech. ${ }^{9}$ Jacobs's study compares the American situation to the most well-known case of forced child removal in the history of settler colonies, the Australian 'Stolen Generations'. In Australia, the forcible removal of mixed-race children from their homes to be sent to foster institutions or 'adopted' by white settler families to 'breed out the colour' ${ }^{\text {'10 }}$ or create 'culturally white people' became the topic of a government-commissioned human rights report, with reparations paid by the government. ${ }^{11}$ These child separation practices were not confined to the former colonies of the United Kingdom. In Belgium, the publications by Sarah Heynssens and by Kathleen Ghequière and Sibo Kanobana on the forced removal of racially mixed Congolese, Rwandan and Burundian children from their birth mothers have caused public indignation. ${ }^{12}$ In 2017, they led to public excuses from the Belgian Catholic Church during the parliamentary discussion concerning the responsibilities of the Belgian colonial administration for the discrimination and removal of mixed-raced children (métisses) in colonial Congo, Rwanda and Burundi. In April 2019, official excuses were offered by the Belgian premier Charles Michel. ${ }^{13}$

These cases have inspired historians to address the issue of child separation in colonial and postcolonial contexts, often including many other, less violent or coercive forms of separation of children from their parents, kin, community and culture as indicated at the start of this introduction. Initially, these studies concentrated on settler colonies, but more recently, studies have appeared of child separation under regimes of European extraction colonies, such as Satadru Sen's Colonial Childhoods, Karen Vallgårda's Imperial Childhoods

Women and Indigenous Child Removal in the American West and Australia, 1880-1940', The Western Historical Quarterly 36:4 (2005) 453-476. DOI: https://doi.org/10.2307/25443236; Margaret D. Jacobs, White Mother to a Dark Race: Settler Colonialism, Maternalism, and the Removal of Indigenous Children in the American West and Australia, 1880-1940 (Lincoln 2009). Commission, Bringing Them Home. A Human Rights Education Resource Developed by the Human Rights and Equal Opportunity Commission. National Inquiry into the Separation of Aboriginal and Torres Strait Islander Children from Their Families (Sydney 2003); New South Wales Parliament, Reparations for the Stolen Generations in New South Wales (Sydney 2016), https://www. parliament.nsw.gov.au/committees/inquiries/

Pages/inquiry-details.aspx?pk=1645\#tabotherdocuments. Accessed 4 February 2020. Kathleen Ghequière and Sibo Kanobana, De bastaards van onze kolonie: Verzwegen verhalen van Belgische metissen (Roeselare 2010); Sarah Heynssens, 'Practices of Displacement: Forced Migration of Mixed-Race Children from Colonial Ruanda-Urundi to Belgium', Journal of Migration History 2:1 (2016) 1-31. DOI: https://doi. org/10.1163/23519924-00201001; Sarah Heynssens, De kinderen van Save: Een geschiedenis tussen Afrika en België (Antwerp 2017).

13 Belgian Senate Hearing Report with apologies from the Catholic Church: https://www.senate. be/event/20170425-colonization/Compte_ rendu-Verslag.pdf. Accessed 4 February 2020; Declaration by the Belgian Prime Minister: https://www.lachambre.be/kvvcr/pdf_sections/ news/0000009463/metis_verklaring_federale_ regering.pdf. Accessed 4 February 2020. 
and Christina Firpo's The Uprooted. ${ }^{14}$ These studies concern primarily the colonial administration's and missionaries' politics and practices with regard to children of mixed European and indigenous descent, who were legally considered European.

Generally, child separation policies and practices were discursively legitimised as charitable, humanitarian, civilising and/or Christianising projects in which children were 'rescued' from their own so-called poor, primitive, endangered, enslaved, uneducated, heathen or otherwise deficient conditions. Such discourses, enlivened with endearing stories or pictures of 'rescued' children, were a major Christian-humanitarian legitimisation of colonialism. This also affected European children. Elizabeth Buettner, David Pomfret and Karen Vallgårda, discussing the position of European 'imperial childhoods' in the nineteenth and early twentieth century, have pointed to the fact that this was the period in which a supposedly 'universal' concept of childhood as vulnerable, innocent and playful was constructed. In colonial settings as well as in colonial and missionary children's literature, this notion was charged with ethno-hierarchical differences. ${ }^{15}$ For example, white children were prepared for a future role as helpers and civilisers of their less fortunate 'little brown brothers and sisters' ${ }^{16}$

Colonial governmentality and politics of generation

In this issue, we argue that children were key to imperial ambitions to reshape the indigenous population into governable subjects. ${ }^{17}$ Thereby, David Scott's

Orphanage, child and authority in British
India', The Indian Economic \& Social History
Review 44:4 (2007) 463-488. DOI: https://doi.
org/10.1177/001946460704400403; Satadru Sen,
Colonial Childhoods: The Juvenile Periphery of
India, 1850-1945 (London 2005). DoI: https://doi.
org/10.7135/upog781843313625; Christina Elizabeth
Firpo, The Uprooted: Race, Children, and Imperialism
in French Indochina, 1890-1980. Southeast Asia:
Politics, Meaning, and Memory (Honolulu 2016);
Vallgårda, Imperial Childhoods; Felicity Jensz,
'Missionaries and Indigenous Education in the
19th-Century British Empire. Part I: Church-State
Relations and Indigenous Actions and Reactions',
History Compass 10:4 (2012) 294-305. DoI: https://
doi.org/10.1111/j.1478-0542.2012.00839.x; Felicity
Jensz, 'Missionaries and Indigenous Education in
the 19th-Century British Empire. Part II: Race, Class,

and Gender', History Compass 10:4 (2012) 306-317. DOI: https://doi.org/10.1111/j.1478-0542.2012.00838.x.

15 See among others: Vallgårda, Imperial Childhoods; David Pomfret, Youth and Empire: Trans-Colonial Childhoods in British and French Asia (Stanford 2016); Hugh Morrison, 'The "joy and heroism of doing good": The New Zealand Missionary Record and Late-Nineteenth-Century Protestant Children's Missionary Support', Journal of New Zealand Literature (JNZL) 28:2 (2010) 158-182; and Wesseling in this issue, 'Brown Nieces and Nephews in an All-White World: Gender and Genre in Dutch Children's Novels about the Dutch East Indies, 1890-1930', BMGN - Low Countries Historical Review 135:3/4 (2020) 184-208. DOI: https://doi.org/10.18352/bmgn-lchr.10877. Vallgårda, Imperial Childhoods, 209-234.

For the relation between governing and legibility, see James C. Scott, Seeing Like a State: How 
groundbreaking essay 'Colonial Governmentality' is of central importance to our understanding of colonial politics. Late colonial politics, he argued, 'aimed for a colonial governmentality (...) so as to produce not so much extractiveeffects on colonial bodies as governing-effects on colonial conduct'. ${ }^{18}$ It builds on the crucial insight of Foucault that power is not restricted to the sovereign exercise of coercion and violence, but extends to all kinds of discourses and practices shaping governable or 'disciplined' subjects. These involve routines and techniques which enable administrations to oversee, sort, direct, transform and control populations on both micro- and macro-levels.

Ann Laura Stoler was the first to connect issues of governmentality to the problem of marking colonial difference. After all, the racial and other hierarchies on which colonial rule rested, demanded a continuous maintenance of their boundaries. She demonstrated how that happened primarily at female-gendered sites such as the household, education and childcare, as well as through strict regulations of sexuality. Therefore, she famously declared 'matters of intimacy' to be 'matters of state', sharply articulating how micro-policies of the household were essential to colonial rule. ${ }^{19}$ Based on Stoler's work, Geertje Mak introduced the Dutch word geslacht (in one word referring to gender, sex, generation and lineage) to be able to recognise how colonial governance was carried out through a politics 'from generation to generation'. Children were crucial to Dutch colonial policies aiming at a transformation of colonial conduct, she argued, as they were the easiest to access, and the most pliable. Moreover, they formed the future. ${ }^{20}$

Intervening in the lives of new generations of colonisers and colonised was a crucial strategy for transforming, disciplining, controlling and directing people and populations. This is particularly true for the late colonial period of the Dutch East Indies and its 'Ethical Policy', the Dutch version of the 'mission civilisatrice', or the white (wo)man's burden. Several studies of Dutch colonial rule in the East Indies have already shown how mixed-race children appeared as both 'at risk' and 'a risk' to colonial administrations, as the influences of their coloured birth mothers or their own culture threatened to break down colonial boundaries. A similar argument has been made by Sarah Heynssens with regard to orphaned métis children in Congo. ${ }^{21}$ In comparison to

Certain Schemes to Improve the Human Condition Have Failed (New Haven 1998).

Geertje Mak, Huishouden in Nederlands Nieuw Guinea: Geschiedenis van geslacht op geslacht (Amsterdam 2017).
21 For the apt expression 'a risk' and 'at risk', see: Joost Coté, "The sins of their fathers": culturally at risk children and the colonial state in Asia', Paedagogica Historica 45:1/2 (2009) 129-142. DOI: https://doi.org/10.1080/00309230902746438; Ann Laura Stoler, Race and the Education of Desire: Foucault's History of Sexuality and the Colonial Order of Things (Durham 1995); Ann Laura Stoler, Carnal Knowledge and Imperial Power: Race and the Intimate in Colonial Rule (Berkeley 2002); Annelieke Dirks, For the Youth: 
mixed-race children, indigenous children were more often presented as in actual danger of life in order to legitimise 'saving' these children. This legitimation only applied to métis children in Congo and Eurasians in the Dutch East Indies during the periods of decolonisation. ${ }^{22}$ However, colonial interventions in the lives of children were by no means restricted to late colonial civilising projects, as Bente de Leede argues in this special issue. Her case study concerning voc government in eighteenth-century Sri Lanka demonstrates that the voc, in alliance with the Church, targeted children in their attempts to create colonial subjects.

Colonial, humanitarian or missionary discourses, policies and practices of child separation, therefore, did not 'just' harm private lives, families or cultures, nor did they 'only' create a morally superior white selfunderstanding as do-gooder. They enabled colonial and imperialist powers to create governable subjects and were thus central to colonial power. The centrality of the child in colonial politics can be extended to childbirth and -care, as Nancy Rose Hunt has argued for Congo, where missions, health care, pronatalist policies and colonial governmentality were deeply entangled. ${ }^{23}$ However, apart from Maaike Derksen's analysis of the Catholic mission in southern Dutch New Guinea, in which low birth rates formed an important argument for intervention, this special issue does not further deal with this aspect.

Missionaries' interferences and 'humanitarian' interventions are easily deemed marginal in contrast to what is often considered the 'core' issue of colonialism - political domination, economic extraction, military interventions and war. However, together with Stoler and Scott, we would like to argue that 'hard' and 'soft' aspects of colonialism need to be analysed as intertwined rather than as opposed, as colonial power rested on the daily (re)creation of colonial hierarchies and on the disciplining of its subjects. In particular against the background of current public discussions, both in Belgium and in the Netherlands, in which exploitation and domination are 'balanced' against the 'good things we also brought', it is crucial to expose their intrinsic, complex entanglements. Understanding both the good intentions and their deep entanglement with (post)colonial power structures,

Juvenile Delinquency, Colonial Civil Society and the Late Colonial State in the Netherlands Indies, 18721942 (Dissertation; Leiden University 2011) 46-69; Jean Gelman Taylor, The Social World of Batavia: Europeans and Eurasians in Colonial Indonesia (Madison 2009); Ulbe Bosma and Remco Raben, Being "Dutch" in the Indies: A History of Creolisation and Empire, 1500-1920 (Singapore/Athens 2008); Heynssens, 'Practices of Displacement'. (DOI: https://doi.org/10.18352/bmgn-lchr.10876),
Monteiro (DOI: https://doi.org/10.18352/bmgnIchr.10875) and Derksen (DOI: https://doi. org/10.18352/bmgn-lchr.10874) in this issue.

23 Nancy Rose Hunt et al., A Colonial Lexicon of Birth Ritual, Medicalization, and Mobility in the Congo (Durham 1999). See also: Liesbeth Hesselink, Healers on the Colonial Market: Native Doctors and Midwives in the Dutch East Indies. Verhandelingen van het Koninklijk Instituut voor Taal-, Land- en Volkenkunde 276 (Leiden 2011). DOI: https://doi. org/10.1163/9789004253575. 


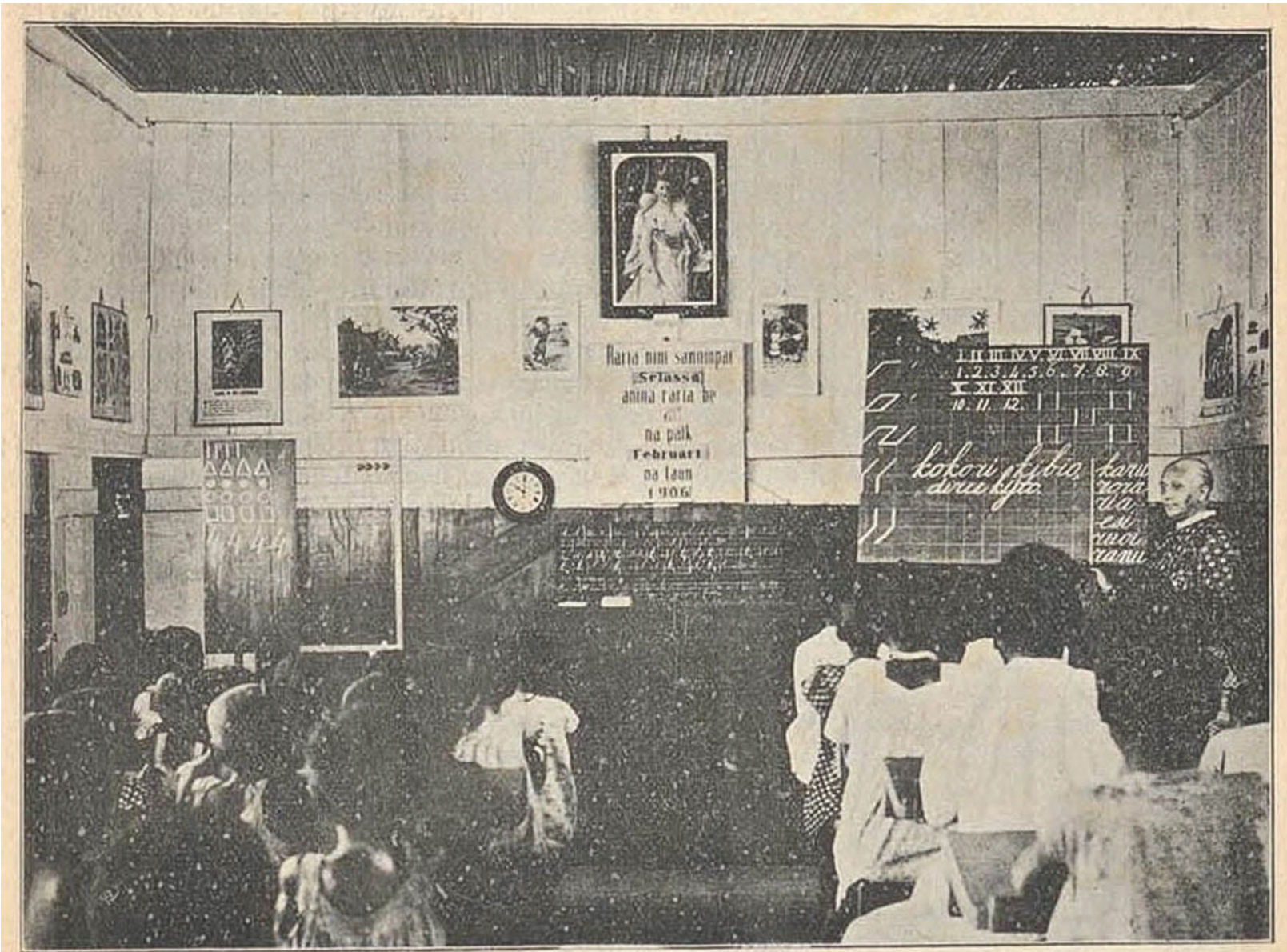

School te Windessi, met Njonja en de leerlingen.

$\Delta$

A school interior at Windesi (Dutch New Guinea), showing how children are placed in a Western and Dutch national order, with the portrait of the Queen overlooking the class, the Windesi children in rows behind their tables overseen by the 'nonja' (M.L. Van Balen-Michaux), clock and indication of date, transcriptions of Windesi language in Latin alphabet, roman and Hindu-Arabic number system. The accompanying text comments puts its readers in the position of assessing the 'progress' of the Windesi children, which simultaneously forces them to internalise its implicit moral standards. $^{24}$

24 Het Penningske 6:9 (1906) 1. https://resolver.kb.nl/ resolve?urn=MMZEND01:002721009:00001. 
is an important contribution to the current societal debates about colonial history. While current public voices urgently insist on critically distancing ourselves from histories of slavery, colonial violence, exploitation and its underlying systemic racism, the issue of 'soft colonialism' might require close and (self)critical scrutiny of our involvement and investments. This would enable us to see patronising and often disastrous consequences of a peculiar, yet historically persistent Western 'will to improve' other societies. ${ }^{25}$

\section{Christian colonial missions}

The encounters of Christian missionaries with indigenous and nonindigenous local actors have become vital to Anglophone New Imperial History. ${ }^{26}$ New Imperial History was critically inspired by pioneering work on the role of missions, starting with Jean and John Comaroff's work and followed by Jeffrey Cox and Tony Ballantyne. ${ }^{27}$ The label 'Christian colonial missions', recently used by the Australian historian Claire McLisky, aptly summarises the Christian missions' deep entanglements with colonial structures and culture. This characterisation acknowledges that we need to understand and incorporate the lasting social and cultural impact of the Christian missions as colonial projects in contemporary postcolonial societies. $^{28}$

Surprisingly, however, missions and religion more generally have been almost entirely left out of the framework of Dutch colonialism as interpreted through the lens of (gendered) governmentality. Stoler, for instance, does not pay attention to the missions as key actors in carrying out policies of 'orphaning' Eurasian children with a living indigenous mother nor does she take religion into account in her analysis of 'grammars of difference' within the Dutch East Indies society. Dutch mission historiography - both in monographs on separate missions and in overviews - describes the development of Christianity in the colonies as a separate history in terms of Christian ideals, prescribed mission methods, achieved conversions and the creation of Indonesian Christian communities and institutions. From this

Development, and the Practice of Politics (Durham 2007). 6-8.

Jean Comaroff and John Comaroff, Of Revelation and Revolution, Volume 1: Christianity, Colonialism, and, Consciousness in South Africa (Chicago/ London 1991); Jeffrey Cox, Imperial Fault Lines: Christianity and Colonial Power in India, 1818-1940
(Stanford 2002); Catherine Hall, Civilising Subjects: Metropole and Colony in the English Imagination, 1830-1867 (Cambridge 2002); Tony Ballantyne, Entanglements of Empire: Missionaries, Maori, and the Question of the Body (Auckland 2014).

Claire Louise McLisky, 'Introduction to Colonial Christian Missions: Social and Cultural Impacts and Ongoing Legacies', Journal of Social History 50:3 (2017) 457-465. DOI: https://doi.org/10.1093/ jsh/shwo44. 


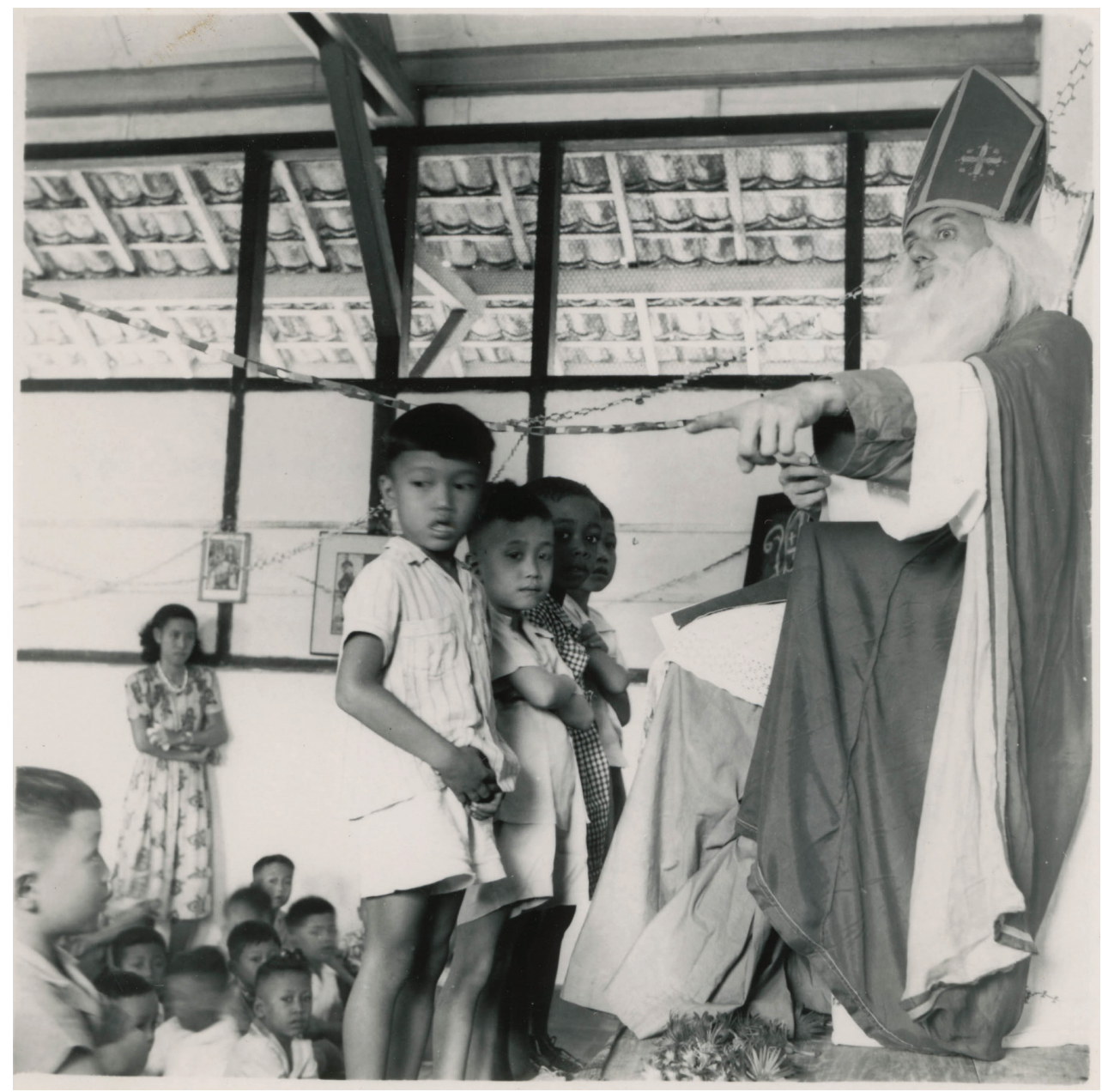

$\Delta$

With the export of European education, Dutch missionaries also introduced children's holidays to their missionary institutes in Java, such as 'Sinterklaas' celebrated on December 5. This figure was loosely inspired on an early Christian bishop from the Mediterranean, but transformed into a stern, yet benign judge of children's conduct. The children sang specific songs, 'Sinterklaasliedjes', in order to placate the holy man. They would receive gifts and candy if they had been 'good' during the previous year. However, if they had been 'naughty', they had to reckon with the threat of being punished with the 'rod'. Naturally, this threat was not carried out but was supposed to contribute in a playful way to disciplining children according to European standards, which also granted the missionaries more profound influence over them. This picture was taken at an elementary school for Indo-Chinese in Semarang in 1951. Apparently one of the Dutch missionaries - a Jesuit most likely - had dressed up as 'Sinterklaas'. The children in front of him were supposed to report about their conduct, but seem to have been distracted. The caption on the back of the photo reads in Dutch that small Chinese can be naughty too. ${ }^{29}$ 
perspective, Christian and missionary opinions and attitudes towards colonial ideals and policies are described. ${ }^{30}$

While Christian missions were only partially funded by the colonial administration to provide pastoral care for the very small European proportion of the inhabitants of the colony, the ambitions of the missionaries expanded in the second half of the nineteenth century to reach the local populations. In this context, some missionaries criticised the colonial system and colonial exploitation; others started to develop missionary strategies geared at indigenous inhabitants. For example, Protestant missions increasingly educated children by taking them into their houses (the anak piara system), where these children also provided house services for the missionaries and could expect to be rewarded with a job within the mission afterwards as teacher or 'guru', or, for girls, with marriage to a guru. Towards the end of the nineteenth century Catholic and Protestant missionary goals and the 'Ethical' policies converged in the field of education and juvenile care. From 1890 onwards, subsidies for schools greatly enhanced missionary opportunities. In full ideological agreement with the colonial administration's 'civilising mission', missionaries increasingly started to support the colonial project in general. What is lacking in this historiography, however, is the deep, implicit entanglement of missionary and colonial projects and practices in terms of governmentality - the creation, disciplining and managing of colonial subjects. ${ }^{31}$

Belgian historiography is positioned somewhat differently in these debates. Because the role of missions in Belgian Congo has been much more apparent, there is also a much longer tradition of discussing the relation between missions, Leopold's Congo and Congo as a Belgian colony, in general and with regard to health care and education. Most discussions concentrate on missionary perspectives on colonial rule and their own role in, for example, education. These evaluations mostly point to much difference of opinion and attitudes among missions. Moreover, the colonial state and missions did not

Schools in Batakland (Indonesia), 1861-1940 (Leiden/ New York 1994). In the first chapter of this book, Aritonang gives an excellent overview of the history of colonial education in the Dutch East Indies and the relations between missions and government this entailed.

31 Aritonang, Mission Schools, 328-331; Henri Théodore Fischer, Zending en volksleven in Nederlandsch-Indië (Zwolle 1932) 180-183. Maaike Derksen, Embodied encounters: Colonial governmentality and missionary practices in Java and Dutch New-Guinea, 1856-1942 (PhD-thesis; Radboud University Nijmegen, specifically Chapter 3. 


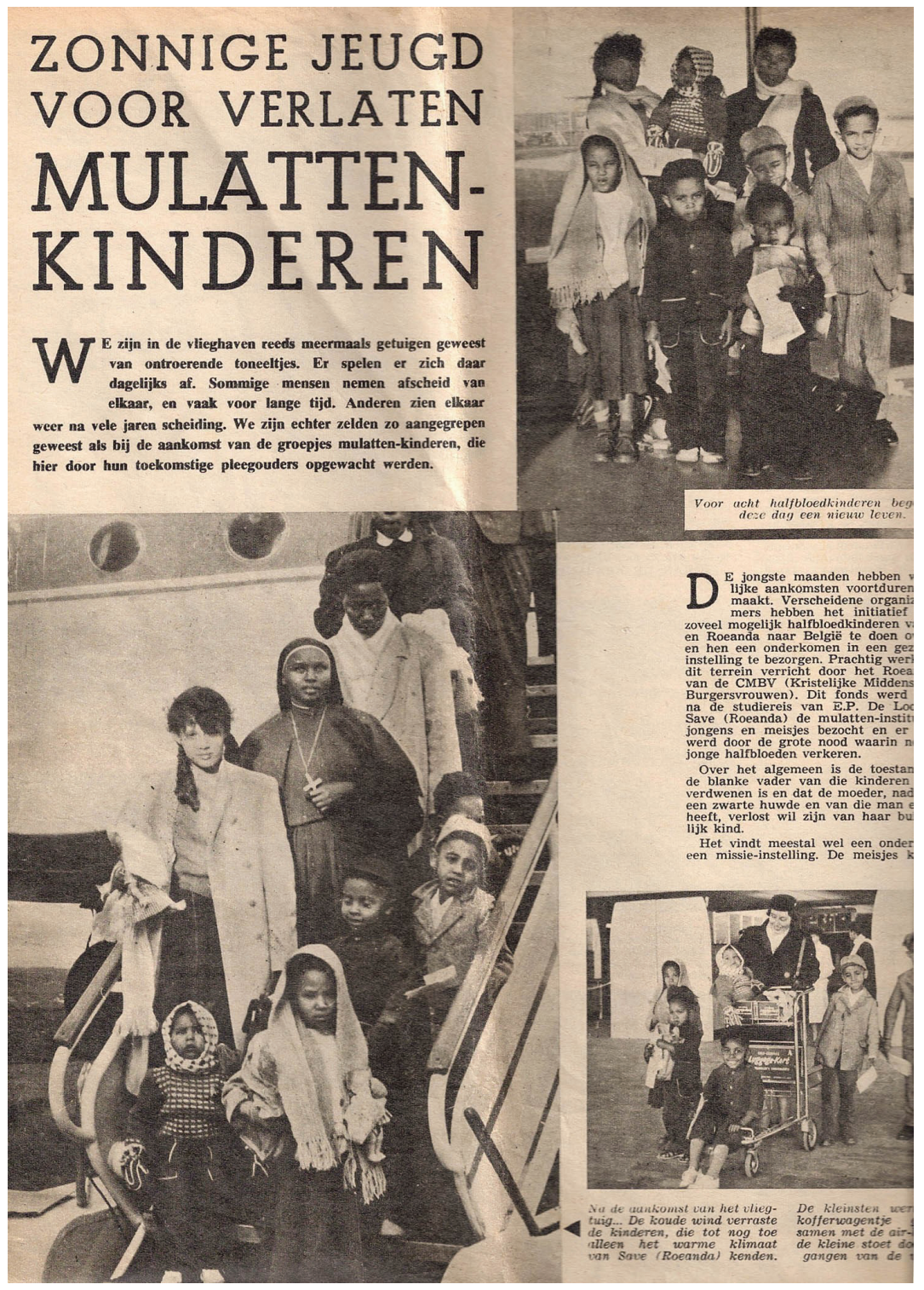

\section{$\mathbf{\Delta}$}

The title of this article about the arrival of young migrants from Ruanda-Urundi in Belgium translates as 'A Sunny Youth for Abandoned Mulatto Children'. These children are stepping into a new life in Belgium, where they were to be adopted by Belgian families or placed in children's homes. Their transfer was facilitated by the Christelijke Middenstands- en Burgersvrouwen (Society for Christian Middle-Class Women), revealing the ongoing involvement of the Catholic Church in child separation in postcolonial Belgium, in close conjunction with humanitarian (women's) volunteer organisations. Every word in the title is questionable. Adult adoptees have declared that their youth was not necessarily all that sunny, 'mixed' children were often wrongly labeled as orphans, while 'mulatto' is a racist term for referring to persons with a white and a black parent. ${ }^{32}$

\section{2 'Zonnige jeugd voor verlaten mulattenkinderen',}

Ons Volk 43:3 (1960). 
always have the same agenda; Loffman characterised their relation recently as a 'competitive co-dependency'. ${ }^{33}$ The mission's role in creating colonial governmentality (and local responses to that) is best analysed in a study not concentrating on child separation, but on maternal care. ${ }^{34}$

While a variety of studies of both Dutch and Belgian colonial missions thus do indeed indicate the role of education of children in a civilising project from the late nineteenth century onwards, the analysis lacks a profound questioning of the discourses, policies and practices by which children and youth could be separated from their own parents, communities and cultures. Moreover, one important aspect that has hardly been touched upon within mission histories is the fact that under the label of education, a complete change of life was intended, including outer appearance, housing, sexual customs and arrangements, work ethics and order of time - a colonial policy aiming at transformation of its subjects. ${ }^{35}$ Crucially, the question as to how these colonial administrations could actually gain access to and influence over those children is hardly addressed. It is our contention that a next step is necessary, in which the apparently self-evident nature of child separation is challenged by unpacking both the discourses and practices that enabled colonial agents to separate mixed-race and indigenous children from their birth mothers or parents, kin, community and culture.

Studies of child separation have begun to appear in the Netherlands only recently, focusing on specific cases. Annelieke Dirks's dissertation was the first, with a study of reform institutions for juvenile delinquents in the Dutch East Indies between 1900 and 1942. She showed how not only Christian missions and the colonial government, but also the Indonesian Muslim organisation Muhammadijah was involved. ${ }^{36}$ The people managing these reform institutions could gain influence as citizens and spread the lifestyle and ideas of 'modernity'. One of the institutions Dirks discusses

See Marvin D. Markowitz, Cross and Sword: The Political Role of Christian Missions in the Belgian Congo, 1908-1960. Hoover Institution Publication 114 (Stanford 1973) as an early example. For an overview of recent discussions, see: Guy Vanthemsche, 'De verhouding tussen de katholieke kerk en de staat in koloniaal Congo (1885-1960)', in: Dave De Ruysscher, Paul De Hert and Machteld De Metsenaere (eds.), Een leven van inzet: Liber amicorum Michel Magits (Mechelen 2012) 197-242; A.M. Delathuy, Missie en staat in Oud-Kongo 18801914: Witte paters, scheutisten en jezuieten (Berchem 1992); Au, 'Medical Orders', 62; Reuben A. Loffman, Church, State and Colonialism in Southeastern Congo, 1890-1962. Cambridge Imperial and Post-Colonial
Studies Series (Basingstoke 2019). DOI: https://doi. org/10.1007/978-3-030-17380-7. Idesbald Goddeeris helped us find our way in this literature and was so kind to send us his at that time unpublished chapter 'Missionarissen: een menselijker dimensie aan kolonisatie?': Idesbald Goddeeris, 'Missionarissen: een menselijker dimensie aan kolonisatie?', in: Guy Vanthemsche, Idesbald Goddeeris and Amandine Lauro (eds.), Koloniaal Congo: Een geschiedenis in vragen (Kalmthout 2020) 289-304. Aritonang, Mission Schools, for example, is an excellent study of the encounter of Batak and colonial education, but restricted to education 'proper'. 
is the best studied and documented case of child separation in the history of the Dutch East Indies, namely the orphanage run by 'Pa van der Steur' (Father Van der Steur). He allegedly managed to give shelter to 7,0oo orphans, mostly of Eurasian descent. Until this day, his achievements have been hailed, even by the organisation of former pupils in the Netherlands. A thorough critical questioning of the exact status of the 'orphans' - for example, by checking whether their birth mother had still been alive - is almost entirely lacking, however. ${ }^{37}$ Kirsten Kamphuis's dissertation also combines Protestant missionary and other (nationalist and Muslim) educational opportunities in her comparison of girls' education in highly varying contexts in the Dutch East Indies between 1880 and the end of Dutch rule. ${ }^{38}$ Both her and Dirks's studies show that Dutch colonial policies in the twentieth century had extended their efforts to civilise intimate lives beyond (Indo-) European families to indigenous families, as this special issue will further confirm. The work of Maaike Derksen is as groundbreaking with regard to the Catholic missionary schools set up to create Catholic Javanese guru families. ${ }^{39}$ In Belgium, Kathleen Ghequière and Sibo Kanobana recorded the testimonies of métis children declared orphans and moved to Belgium after decolonisation, a story of orphaning and forced intercountry 'adoption' further examined by Sarah Heynssens. Both studies emphatically include the adoptees' perspectives. ${ }^{40}$ These pioneering studies of early career scholars demonstrate the necessity of a more systematic analysis of child separation in the Dutch East Indies, and in Leopold's or Belgian Congo in which it is already considered a key theme of (post)colonial history.

\section{Questioning the humanitarian aura of child separation}

We are keenly aware that a critical analysis of colonial governmentality runs the risk of obscuring or neglecting the agency of the colonised: the separated children, their parents, kin and community. This question of

Carl Brakkee, Pa van der Steur: Vader van 7000 kinderen (Apeldoorn 1996); Vilan van de Loo, Johannes "Pa" van der Steur (1865-1945): Zijn leven, zijn werk en zijn Steurtjes. Biografie (The Hague 2016). Dirks only devotes a few critical remarks to the fact that Van der Steur took children from their birth mothers, and takes over the word 'orphans' in speaking about them (Dirks, For the Youth, 67-69). in a changing colonial society: the Dutch East Indies,
C. 1880-1942 (Dissertation; European University

Institute Florence 2019). DOI: https://doi. org/10.2870/58229. need to graft the European civilization": Fashioning local intermediaries in the Dutch Catholic mission, 1900-1942', Tijdschrift voor Genderstudies 19:1 (2016). DOI: https://doi.org/10.5117/TVGN2016.1.DERK. Heynssens, 'Practices of Displacement'; Ghequière and Kanobana, De bastaards van onze kolonie. 
agency in colonial culture has fuelled recent scholarly debates about archives and colonial knowledge. Ricardo Roque and Kim A. Wagner resist an overall denouncement of colonial sources as only representing stereotypical 'others', and insist that 'colonial accounts constitute embodied artefacts that, through careful examination of their relative potential and limitations, can offer important insights into the colonial phenomenon and into European as well as Indigenous actions and cultures in the past' as a strategy to trace and extract Indigenous voices and perspectives from colonial collections. ${ }^{41}$ Roque and Wagner suggest three different kinds of reading of colonial archives, each of which is used in this special issue, often together.

The analysis of material forms and structures of archives alongside their contents, to grasp and be able to clarify in what ways colonial categories and frames literally materialised in archival collections constitutes the first layer - a reading along the grain. Such a reading helps to disrupt the unintentional replication of the discursive and performative leverage of colonial archives..$^{42}$ In this issue, several contributions indeed expose the labelling, categorising, narrating and overall framing of colonial archives and policies which designed, idealised and legitimated interventionist civilising offences. In this issue, Chiara Candaele detects such dynamics in the labelling of prospective adoptees from Rwanda and their birth mothers in adoption files of a Catholic missionary agency in Belgium. Notions such as 'rootless' and in need of becoming 'rooted again' in a 'proper' family explain how Belgian adoptive parents could take precedence over the birth mothers of the Rwandan children. Moreover, Candaele uses publications and archival sources from the two main Catholic adoption agencies, reports from the Flemish agency for child welfare (Kind en Gezin) and adoption

Colonial Knowledge: Reading European Archives

in World History. Cambridge Imperial and Post-

Colonial Studies Series (Basingstoke/New York 2012). DOI: https://doi.org/10.1057/9780230360075;

Maaike Derksen and Margriet Fokken were the first to apply these reading strategies to the untapped richness of Dutch Christian mission archives: Maaike Derksen and Margriet Fokken, 'Gender and (post)colonialism. Locating marginalized voices', Tijdschrift voor Genderstudies 18:3 (2015) 245-253. DOI: https://doi.org/10.5117/ TVGN2015.3.DERK.

Ann Laura Stoler, Along the Archival Grain:

Epistemic Anxieties and Colonial Common Sense

(Princeton 2009); Victoria Haskins, 'Decolonizing the archives: A transnational perspective', in:
Kirsty Reid and Fiona Paisley (eds.), Sources and Methods in Histories of Colonialism: Approaching the Imperial Archive. Routledge Guides to Using Historical Sources (Oxford/New York 2017) 47-50. DOI: https://doi.org/10.4324/9781315271958-4. Compare the forum on archival management and research practice concerning the voc Archives, introduced by Alicia Schrikker, BMGN - Low Countries Historical Review 134:2 (2019) 96-152, in particular the contributions of Michael Karabinos 'Decolonisation in Dutch Archives: Defining and Debating' (129-141) and Jos Gommans, 'Rethinking the voc: Two Cheers for Progress' (142-152). DoI's: http://doi.org/10.18352/bmgn-Ichr.10686, http:// doi.org/10.18352/bmgn-lchr.10687, and http://doi. org/10.18352/bmgn-Ichr.10685. 
case files from the Flemish Central Adoption Authority to analyse how Belgium itself seemingly transformed from a former colonial state into a caring 'motherland' that could provide best for the needs of the children in question. In her article, Elisabeth Wesseling analyses how projects of reallocating and re-educating Eurasian children were 'sold' to Dutch children on the home front, using children's novels as sources. Although these novels are hardly informative about the actual pedagogic practices as such, they are all the more illuminating where the attitudes and values that drove these practices are concerned.

Assuming that colonial texts are often multivocal, a second layer of analysis persistently searches for words, visions and agency of colonised people themselves - a reading against the grain. Kirsten Kamphuis and Marit Monteiro in this issue have been able to trace letters from former pupils of a Protestant school for Javanese girls in Yogyakarta and an orphanage for Chinese children in Semarang and explore the agency of the pupils as well as their background. Marleen Reichgelt concentrates on the movements and actions of the often depicted Marind children and youth from southern Dutch New Guinea by tracing them through different places and ages in a large collection of missionary photography. Bente de Leede reconstructs the negotiations of local parents and their children from schooltombo's registrations of genealogical data and school attendance of the inhabitants of eighteenth-century Sri Lanka.

Finally, and central to this issue, is a turn to the 'how question'. This third layer of analysis explores the actual cross-cultural encounters and material practices in which colonial knowledge is rooted beyond linguistic analysis alone. ${ }^{43}$ How did encounters between missionaries and indigenous people actually take place? How did missionaries build houses, how did they travel, where did they get food, how did they learn the language or otherwise talk to indigenous people? ${ }^{44}$ In their contributions, Geertje Mak and Maaike Derksen use printed and unprinted missionary letters and missionaries' diaries and journals to analyse such 'embodied' encounters. Their investigations yield in-depth knowledge about missionary practices, dependencies and vulnerabilities, as well as the multiple forms of local or 'indigenous' agency. The same is true for the question of which children were available for separation projects and for what reason precisely.

Such analytical operations, to be sure, still put Western scholars and historians with access to colonial and missionary collections in the awkward but nonetheless powerful position of being non-indigenous interpreters of sources that document marginalised and often silenced 'others' in colonial 10-13. and Madness in the Exploration of Central Africa
(Berkeley 2000); Peter Pels, A Politics of Presence: Contacts between Missionaries and Waluguru in Late Colonial Tanganyika (Amsterdam 1999). 
and postcolonial settings. ${ }^{45}$ Yet, we aim to specifically demonstrate that children were not marginal, but rather central to colonial and missionary civilising projects and that their presence, actions and voices can be detected.

\section{Humanitarian imperialism}

The fact that most contributors to this issue turned to missionary archives does not mean that it aims to account for the emergence of indigenous Christian communities, organisations or theologies, nor do we intend to discuss the impact of such developments on contemporary postcolonial Indonesia, Rwanda or Burundi. There is already a good body of literature to cover this. ${ }^{46}$ What we do want to highlight, however, is the long-lasting, structural effects on the ways in which children figure in North-South relations, in particular in postwar continuations of intercountry adoption practices and surrogacy, and affiliated forms of 'humanitarian imperialism'. Vallgårda rightly points out how deeply contemporary discourses of 'rescuing' children from the Third World in 'development' projects and the charity industry as well as in transnational North-South adoption programmes are rooted in colonial practices and discourses that live on surreptitiously and unexamined. In postcolonial times, many colonial missions continue to exist under the flag of humanitarian projects - a continuity in persons, institutions, practices and finances.

As the study by Annelies van Heijst has shown for the history of Dutch Catholic humanitarian aid projects, new Christian organisations came into being after the Second World War which were rooted in pre-war missionary projects and funded by the Dutch administration. They reconceived their previously religious missions as humanitarian and educational ones, while claiming long-standing expertise in the field. Colonial discourses and practices of the Christian missions thus spilled over into these secular humanitarian projects that were founded upon implicit Christian tenets. ${ }^{47}$ There is no doubt that children figure prominently in these successor projects, but how precisely they do so in the history of development aid of the Low Countries remains to be analysed. Theoretically, the critical work by Didier Fassin, Miriam Ticktin and Olga Nieuwenhuijs on the trope of 'innocence' in 'humanitarian government' may clarify that children are not positioned 'outside' politics, but smack in the middle of it - whether as agents or as

47 Annelies van Heijst, Gedreven helpers: Een geschiedenis van Cordaids voorlopers. RK Huisvestingscomité, Mensen in Nood, Memisa, Medicus Mundi, Indische Missie Vereniging, Centraal Missie Commissariaat, Cebemo, Vastenaktie, Bilance en Bond zonder Naam (Hilversum 2014).

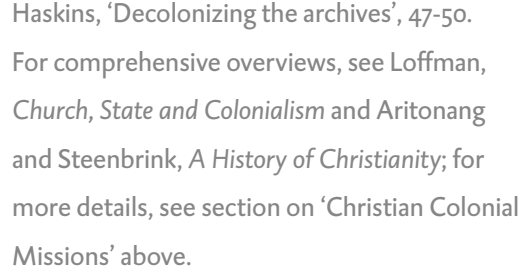


idealised objects of intervention. ${ }^{48}$ Such a critical analysis demands thorough scrutiny of the connections between colonialism, the conceptualisation of 'true' childhood as innocent, and the colonial clichéd comparison of colonised peoples with children. ${ }^{49}$

While interventions into indigenous and mixed families once served the emancipation of white Western women, nowadays, intercountry adoption and surrogacy support the claims of gay couples to the right to found a family of their own. Then and now, these projects are often carried out with the best intentions. The fact that intercountry adoption tends to be dated from the 1950 onwards is indicative of widespread cultural amnesia concerning colonial child separation projects in continental European empires. ${ }^{50}$ As Elisabeth Wesseling also argued elsewhere, just as intercountry adoption did not emerge like a bolt out of the blue in the 1950s, global surrogacy is not fully 'new' either. The apparently self-evident fact that adoptees and children obtained through surrogacy travel from the global South to the global North rather than the other way around should make us pause and ponder the global asymmetries involved. Once again, the emancipation struggles of a group in the West (this time gays) and interventions in the reproductive lives of non-Western persons have become entangled, producing the ethical and political quagmire that the global West has faced quite a few times before. A historical perspective is indispensable to acquiring full awareness of such ethical quandaries. ${ }^{51}$

\section{Contributions}

Several contributions to this issue offer detailed reconstructions of the ways in which missionaries and affiliated 'civilisers' gained access to indigenous children and were granted the opportunity to shape them, although never to the extent of their own liking. Geertje Mak, Maaike Derksen and Marleen Reichgelt all present case studies of child separation projects in former Dutch New Guinea.

Olga Nieuwenhuys, 'Theorizing childhood
Why we need postcolonial perspectives',

Childhood 20:1 (2013) 3-8. DOI: https://doi.

org/10.1177/og07568212465534; Didier Fassin,

Humanitarian Reason: A Moral History of

the Present (Berkeley 2011); Miriam Ticktin,

'A world without innocence', American

Ethnologist 44:4 (2017) 577-590. DOI: https://

doi.org/10.1111/amet.12558; Kristen Cheney

and Aviva Sinervo (eds.), Disadvantaged

Childhoods and Humanitarian Intervention:

Processes of Affective Commodification and

Objectification. Palgrave Studies on Children and

Development (Basingstoke 2019) DOI: https://doi. org/10.1007/978-3-030-01623-4.

49

50

51

Genealogies for Intercountry Adoption', Adoption

\& Culture 6:1 (2018) 30-32. DOI: https://doi.

org/10.26818/adoptionculture.6.1.0001. 
Geertje Mak addresses the question of how Dutch missionaries could get hold of indigenous children in the late nineteenth century in the first place. Missionaries in this region frequently resorted to buying their future converts - 'ransoming', in missionary parlance. The question then becomes how these children had become commodified, which Mak explains at length through the complex interplay between indigenous gift cultures - with children circulating between tribes to repair wrongs and redress the balance of power - the international trade market, most notably the booming trade in birds of paradise, and a Christian-humanitarian gift economy in which 'rescuing enslaved children' raised money.

Maaike Derksen analyses the reform strategies which Dutch Catholic priests and brothers of the Sacred Heart of Jesus employed to distance Marind-anim children from their next-of-kin and local culture during the first two decades of missionary and colonial culture (1905-1921). She reveals the importance of bodily practices in these concerted efforts to uplift Marind society as implemented in boarding schools and in the new villages designed by the colonial administration, providing concrete insight into the ways in which governmentality was instilled in indigenous youth.

Marleen Reichgelt offers a close reading of early twentieth-century photographs of Marind-anim children by missionaries of the Sacred Heart of Jesus. She approaches the photographed children as protagonists rather than passive, silent objects, thus offering a fine example of reading against the grain. Reichgelt deduces the different modalities of colonial encounters between missionaries and indigenous children from these pictures, uncovering how the latter subverted age classifications to escape coerced education. Like Derksen, Reichgelt also reveals how the bodies of indigenous children became contested sites under the colonial and missionary regimes, which does not imply that these 'objects of reform' were deprived of all forms of agency.

Bente de Leede demonstrates that policies targeting children were not restricted to the late colonial era and its explicit civilising aims. She examines data on local children and youth in Sri Lanka gathered by representatives of the Dutch Reformed Church which geared towards the needs of the Dutch East India Company: civil and productive subjects who would perform mandatory services, in accordance with age and caste, after finishing elementary school. De Leede's analysis shows how local parents and their offspring both resisted and negotiated such categorisations which were intended to enhance and exploit their governability.

Kirsten Kamphuis and Marit Monteiro inquire into collaborations between local elites and colonial charity organisations in running Dutch schools for indigenous children. Kamphuis focuses on the Koningin Wilhelmina School on Java for the daughters of the Javanese nobility in the first decades of the twentieth century. She investigates the aims of the Protestant elite running the school and the ways in which they tried to implement these goals, while also addressing the question of why Javanese Muslim aristocrats would ever consent to exposing their daughters to 
Christian influence. She reveals that the aims of the colonial and indigenous elite were clearly at odds with one another, the first striving to make the pupils susceptible to the Christian faith, while the latter used the school to secure the position of their children within the colonial elite. Kamphuis's perusal of the letters which the pupils wrote also reveals that conversions were in fact rare. Monteiro studies an orphanage for Chinese children run by Catholic missionaries in Kebon Dalem, Semarang in the 1930s. Interestingly, this orphanage received substantial support from the local Chinese elite, who sat on its board of governors and contributed funds. Here, again, we may witness how missionaries and local elites pursued their own separate aims through complex entanglements and complicities. Catholic missionaries approached underprivileged Chinese children as potential 'cultural circuit breakers' who could help to usher in a Western, Christian value regime. Meanwhile, the local Chinese elite wanted to flaunt their capacity for self-rule by sharing responsibility for the orphanage with the missionaries, and to perpetuate Chinese charitable traditions. The case studies of both Kamphuis and Monteiro invite further investigation into the investments and interests of local elites in child separation practices of Christian civilising projects.

Elisabeth Wesseling's article then illuminates how the moral uplift of children in colony and metropole went hand in hand. It analyses how projects of child separation in the Dutch East Indies were 'sold' to Dutch children on the home front through children's literature written under the aegis of the Ethical Policy. Clearly, children's narratives made a serious effort to win the hearts of Dutch children for the civilising projects in the East Indies, recruiting the next generation of colonial administrators, missionaries and entrepreneurs. Although most of the children's novels discussed are totally forgotten by now, a reconstruction of the ways in which projects of reallocating and re-educating children from the Dutch East Indies were propagated on the home front is a necessary precondition for acquiring an awareness of the continuities between colonial and postcolonial dealings with children in Europe's (former) colonies.

A critical study of these continuities is the topic of Chiara Candaele's contribution, who brings us back to our current day and age. Candaele concentrates on two Belgian Catholic adoption agencies who mediated adoptions of children from the present-day Rwanda and Burundi. She not only discerns the missionary roots of these adoptions in (dis)continuities with colonial actors, practices and narratives; she also importantly demonstrates how these children figure in shaping an image of Belgium as a nation, shifting from the former patriarchal role of the 'humanising' coloniser to one in which the nation becomes a 'mother' of children from the formerly colonised territories.

With this variety of cases of (post)colonial child separation in the Low Countries, this special issue connects Dutch and Belgian histories to the booming international historiography in this field. It thereby shows Dutch colonial history not to be that exceptional - only its historiography has persistently omitted to integrate its crucial religious and missionary 
aspects..$^{52}$ But there is more: while arguing its key role in (post)colonial policies, this issue also accounts for the enormous variety in actual child separation practices and discourses. We have to distinguish between strategies targeting mixed-race children and local children in the first place. While the first were 'at risk' and 'a risk' for the category of Europeans, local children proved to be often the most important point of access to civilising missionary projects. With regard to mixed-race children, the long-term history of legally, discursively and actually orphaning or adopting children in the (post)colonial histories of the Low Countries urgently begs for more in-depth research than we have been able to provide here with Candaele's and Wesseling's contributions. In the case of local children, we see crucial differences between strategies trying to seduce local elites to lend their children to such projects, and strategies targeting 'outcasts'children in a weak position within or separated from their birth communities. These different contexts and strategies also show a wide variety of agency of local people, such as cooperation and strategic alliances, curiosity, negotiation, positive integration into one's life history, as well as refusal and resistance.

Geertje Mak is professor Political History of Gender at the University of Amsterdam and researcher at the humanities research group NL-Lab of the Dutch Royal Academy of Science. Historicising categories of difference and identities form the core of her work. She published in Dutch and internationally on the Western European history of the relation between bodies and selves in cases of gender transgression and intersex (such as Doubting Sex: Inscriptions, bodies and selves in nineteenth century hermaphrodite case histories, Manchester 2012), as well as on scientific practices of racial anthropometry in the nineteenth and early twentieth-century (most recently in the 2020 article 'A ColonialScientific Interface: The Construction, Viewing, and Circulation of Faces via a 1906 German Racial Atlas', American Anthropologist, Special Issue Race and Face, https://doi.org/10.1111/ aman.13386). In her Dutch work on migration history in the Netherlands, she focused on the practices of encounters rather than fixed categories. Currently, Mak writes a microhistory of Protestant missionaries in Dutch New Guinea from the perspective of the theoretical notion of 'geslacht'. This Dutch word connotes and connects gender, sex, race and generation, which can be used as key to analyse processes of historical change over generations and the coming into being of (racialised) inherited differences. Together with Marit Monteiro she coordinates the COACC network (Children as Objects and Agents of (Post)Colonial Change). E-mail: geertje.mak@huc.knaw.nl. Susan Legêne, 'The European character of the intellectual history of Dutch Empire', BMGN - Low Countries Historical Review 132:2 (2017) 110-120. DOI: https://www.bmgn-lchr.nl/articles/10.18352/ bmgn-Ichr.10344/. We follow Raben's criticism of the self-image of Dutch colonialism as 'less imperialist', and his suggestion that to overcome this we need to pay attention to the moral ramifications of colonial empires - for example, by investigating the entanglements between colonial administration and Christian colonial missions (Raben, 'A New Dutch Imperial History?', $25,27,29)$. 
Marit Monteiro is professor of cultural and religious history at the Faculty of Arts of the Radboud University, Nijmegen. Her research focuses on religion and cultural memory, (shared and sharing) heritage, gender and intellectual culture. She coorganises the international research network 'Children as Objects and Agents of Change' (COACC; 2018-2021 funded by NWO, the Dutch Scientific Organisation). Its participants analyse the colonial dimensions and impact of missionary endeavours and projects related to local children in colonial and post-colonial contexts. Monteiro was a member of the Commission of Inquiry that investigated cases of sexual abuse of minors in the Roman Catholic Church in the Netherlands (1945-2010), led by the former Secretary of Education Wim Deetman (2010-2011). She was one of the guest editors of the special issue of Trajecta: Religie, cultuur en samenleving in de Nederlanden/ Religion, Culture and Society in the Low Countries 25:1 (2016) on 'Child Sexual Abuse in the Churches: Historical Approaches in Belgium, Germany and the Netherlands'. She currently writes the biography of the Dutch psychiatrist Anna Terruwe (1911-2004) which foregrounds questions of gender and authority in the religion-base health care system in the post-war Netherlands. Recent publications include 'Katholieke psychotherapie in naoorlogs Nederland: Grenzen, gender en gezag in de affaire Terruwe', Tijdschrift voor Geschiedenis 131:2 (2018) 285-308. DOI: https://doi.org/10.5117/TVGESCH2018.2.MONT. E-mail: m.monteiro@let.ru.nl.

Elisabeth Wesseling is professor of Cultural Memory, Gender and Diversity and director of the Centre for Gender and Diversity at the Faculty of Arts and Social Sciences of Maastricht University. She studies the ways in which Dutch educative discourses in children's novels and textbooks were instrumental in selling, silencing and remembering practices of child separation in the Dutch East Indies. Her recent publications include 'Are "the Natives" Educable? Dutch Schoolchildren Learn Ethical Colonial Policy (1890-1910)' co-authored with Jacques Dane for the Journal of Educational Media, Memory, and Society 10:1 (2018) 28-44, and her editorship of the volumes Reinventing Childhood Nostalgia in Contemporary Convergence Culture (London 2017) and The Child Savage (1890-2010): From Comics to Games (Oxford 2016). E-mail: lies.wesseling@ maastrichtuniversity.nl. 